NBER WORKING PAPER SERIES

A NOTE ON LONG-RUN PERSISTENCE OF PUBLIC HEALTH OUTCOMES IN PANDEMICS

Peter Zhixian Lin

Christopher M. Meissner

Working Paper 27119

http://www.nber.org/papers/w27119

\author{
NATIONAL BUREAU OF ECONOMIC RESEARCH \\ 1050 Massachusetts Avenue \\ Cambridge, MA 02138 \\ May 2020
}

We thank Haoze Li and Jingxuan Ma for helpful research assistance. Guido Alfani, Matthias Blum, Gregori Galofré Vilà, Eric Hilt, Dan Liu, Alan M. Taylor, and Sarah Quincy provided helpful comments and suggestions. The views expressed herein are those of the authors and do not necessarily reflect the views of the National Bureau of Economic Research.

NBER working papers are circulated for discussion and comment purposes. They have not been peerreviewed or been subject to the review by the NBER Board of Directors that accompanies official NBER publications.

(C) 2020 by Peter Zhixian Lin and Christopher M. Meissner. All rights reserved. Short sections of text, not to exceed two paragraphs, may be quoted without explicit permission provided that full credit, including ( $)$ notice, is given to the source. 
A Note on Long-Run Persistence of Public Health Outcomes in Pandemics

Peter Zhixian Lin and Christopher M. Meissner

NBER Working Paper No. 27119

May 2020, Revised June 2020

JEL No. H12,I0,N0

\begin{abstract}
Covid-19 is the single largest threat to global public health since the Spanish Influenza pandemic of 1918-20. Was the world better prepared in 2020 than it was in 1918? After a century of public health and basic science research, pandemic response and mortality outcomes should be better than in 1918-20. We ask whether mortality from historical pandemics has any predictive content for mortality in the ongoing Covid-19 pandemic. We find a strong persistence in public health performance in the early days of the Covid-19 pandemic. Places that performed poorly in terms of mortality in 1918 were more likely to have higher mortality today. This is true across countries and across a sample of US cities. Experience with SARS is associated with lower mortality today. Distrust of expert advice, lack of cooperation at many levels, over-confidence, and health care supply shortages have likely promoted higher mortality today as in the past.
\end{abstract}

\author{
Peter Zhixian Lin \\ 1 Shields Ave \\ University of California, Davis \\ Davis, CA 95616 \\ zxlin@ucdavis.edu \\ Christopher M. Meissner \\ Department of Economics \\ University of California, Davis \\ One Shields Avenue \\ Davis, CA 95616 \\ and NBER \\ cmmeissner@ucdavis.edu
}


The most recent global public health scares such as SARS, MERS, Ebola, and H1N1 influenza in 2009 were largely successfully contained without extraordinary levels of excess mortality at the global level. This track record suggests high preparedness and ability to manage pandemics. On the other hand, society has changed in the last 100 years and even in the last decade since the $2009 \mathrm{H} 1 \mathrm{~N} 1$ pandemic.

Our research correlates population mortality rates for Covid-19 today with mortality rates from influenza and pneumonia in the 1918-20 pandemic and with SARS in 2002-03. We do so in a broad sample of countries and for a sample of large US cities.

We find a strong long-run persistence in public health performance. In the weeks and months of the Covid-19 pandemic, places that performed poorly in terms of mortality during the "Spanish flu" were more likely to have higher mortality today. This is true across countries and across a sample of US cities. Our results are robust to inclusion of a range of fixed effects and control variables. The results for the US city data are robust to endogeneity using an instrumental variables strategy.

We also find that there has been some recent success consistent with the possibility of learning (at the societal level) over time. Countries that were more strongly affected by SARS in 2002-03 are likely to have lower mortality rates today, thus far, from Covid-19. These places are mainly in East Asia and have a recent memory of a potentially highly lethal pandemic. As we detail in the discussion, these successes (and failures) when compared to history depend upon a number of deeper social and political determinants. In short "mistrust, isolationism and hubris" matter. These may not be persistent but, whether by coincidence or not, they are arguably present now in the case of the many nations, especially in many Western nations.

\subsection{Preliminary Discussion and Background}

Can we compare public health outcomes in 1918 to today? What drives public health today and in the past? Rapid geographic mobility due to air travel has increased dramatically in recent decades and significantly so with respect to the years 1918-1920. International connections have continued to grow even since 2002, but international cooperation is waning as exemplified by recent US policy. Modern methods of communication like social media, which have emerged in the last decade, complicate the search for accurate content and often create confusion.

Distrust of expert opinion has also heightened in the last decade. In many western societies, including the US, experts have often been replaced with political appointees and civil servants have been granted minimal leeway. Moreover, health infrastructure and accessibility in many countries, even developed and advanced economies, was widely predicted to be incapable of meeting surging demands induced by a pandemic. Such 
bottlenecks can raise cumulative mortality when health care provides viable means of treatment.

In this regard, the public health response to the Covid-19 pandemic represents a significant test of preparedness and whether modern public health systems can do better than they have done historically. Evidently, SARS-CoV-2 and the 1918 H1N1 influenza have different etiologies and epidemiology. Nevertheless, the two pandemics seem to be roughly similar in the magnitude of their case fatality ratios. An estimate of the case fatality rate (CFR) for Covid-19 is 1.34\% while the CFR for the 1918-20 influenza has been estimated to be roughly $2.5 \%$ (Verity et al. 2020 and Short et. al, 2018). ${ }^{1}$

Given these numbers, and modern levels of knowledge and know how, one might strongly expect better performance today. Given the estimated fatality rates, most would predict lower mortality at this point in the pandemic than in 1918-20. After all, humanity has a century of public health research and practice, along with experience gained from SARS, MERS and Ebola. Contingency plans have been formulated at the behest of the WHO and through national initiatives. Non-pharmaceutical interventions (e.g., social distancing) designed to lower peak mortality have been investigated and shown to be effective (Bootsma and Ferguson, 2007; Hatchett et. al, 2007; Markel et. al, 2007).

Recent data make us less sanguine. Figure 1 illustrates that many countries, especially advanced western countries, have had a difficult time in keeping mortality rates below the frontier defined by US mortality rates from flu and pneumonia in 1918 at similar stages in the pandemic. Similarly, Figure 2 shows a number of US states also witnessed mortality rates per 100,000 population above those witnessed in 1918 at a similar stage. These statistics give us pause to re-consider the persistence of pandemic mortality.

We emphasize that our goal in this paper is not to assess the level of mortality in one pandemic versus the other. There are obvious problems comparing distinct diseases and many data measurement issues. Neither do we wish to argue that Covid-19 will be worse in terms of mortality than 1918-20. Instead, we compare relative outcomes across time. We ask whether historical public health performance has any predictive content for public health performance in a recent pandemic. We find that historical experience does help predict recent experience.

\section{Data and Analysis}

\subsection{Data Collection}

We collect data on country-level population mortality from the influenza pandemic of 1918 and from Covid-19. Our baseline country sample covers 33 countries. The sample is

${ }^{1}$ Case fatality ratios for the 1957 and 1968 influenza pandemics were roughly 0.27 and 0.15 (Centers for Disease Control and Prevention, 2007). 
determined by availability of estimated mortality rates from the 1918 influenza pandemic, other control variables, and whether a country had recorded at least on death or confirmed case of Covid-19. Therefore, our sample for cross-country comparison covers those countries subjected to Covid-19 relatively early on in the global pandemic.

Data on mortality from Covid-19 are expressed as the number of total deaths per 100,000 population and are from CSSE Johns Hopkins University (2020). Data on mortality in the 1918 influenza pandemic are also expressed in numbers per 100,000 population and come from Barro, Ursùa and Weng (2020). ${ }^{2}$ These latter figures refer to estimates of excess mortality rates from influenza (or influenza and pneumonia as was common historically) between 1918 and 1920. Excess mortality is defined either relative to normal seasonal mortality from influenza or pneumonia or from all-causes. Barro et. al. (2020) argue that these two types of measures "correspond closely".

We added several data points for the 1918 flu pandemic from secondary sources including Singapore, Hong Kong, and Korea. These are the official deaths from influenza and pneumonia without reference to a baseline level of mortality. Deaths and confirmed cases of Covid-19 were last updated on May 13, 2020 for our sample of U.S. cities and updated on May 21, 2020 for our sample of countries. Our data begin as early as January 21, 2020. For the 33 sample countries, the inter-quartile range of mortality in the 1918 pandemic is 6201360 deaths per 100,000 population with a median of 780 and a mean value of 1120 . This compares to the interquartile range across countries (as of May 21, 2020) for reported Covid-19 deaths of 0.52 to 16.75 per 100,000 and a median of 4.88 .

We supplement the country mortality data with population mortality rates from SARS in 2002-03, GDP per capita in 2018, population density in 2019, some measures of cultural differences such as an index of individualism in a country, and a dummy variable for a tradition of Confucianism. Places coded as Confucianist include mainland China, Taiwan, Hong Kong, Singapore, Japan, and South Korea.

We also explore a historical data base of 46 US cities (Collins et. al, 1930). The total population in these cities is equal to 20.4 million or about $18 \%$ of the US population. Data cover most of the largest cities in the US. We include deaths attributed to influenza and pneumonia, as the rest of the literature has done in the face of historical problems in coding precise causes of death. In these years, the two were often confounded, although they were strongly related.

The mortality from the 1918-1920 influenza pandemic in these cities is expressed as monthly or weekly excess mortality per 100,000 population of 1920 . We use weekly data for the period 10 September 1918 to 13 November 1918, covering the first six weeks of the 1918-20 pandemic for US cities. The excess mortality rates were the differences between the

\footnotetext{
${ }^{2}$ Barro, Ursùa and Weng (2020) rely on an original database of excess mortality from influenza and pneumonia and total excess mortality. The primary data sources they rely on include Johnson and Mueller (2002), Murray, et al. (2006), Mitchell (2007), and the Human Mortality Database (www.mortality.org).
} 
actual mortality rates and the median monthly mortality rates from influenza and pneumonia in previous non-epidemic years in those cities. To make data even more comparable to our data from Covid-19, we convert the weekly excess deaths to daily observations by linear interpolation within the week to calculate daily cumulative excess deaths since the first week of September 1918.

We match US cities with continuous historical data to modern city or county-level data. One issue associated with the long-run city-level comparison is that Covid-19 data are separately reported only for some cities in our sample (New York City, St. Louis, Richmond, etc.) while most data is reported at the county level. For cities in the historical sample without separately reported Covid-19 data at the city-level, we use data from the counties where the cities are located in. For example, we pair the 1918 data for Detroit with Wayne County today.

To calculate event time, we set a threshold level of mortality at the city level of 0.5 per 100,000 for each pandemic. Event time and observations begin as per this threshold mortality rate. This threshold was chosen since this is the lowest recorded threshold for excess deaths from influenza and pneumonia we have available in the historical city-level data in 1918-20.

\subsubsection{Analysis: Countries}

Our first test finds significant persistence of public health performance across countries. In Figure 3, we plot the average daily growth rate of the total reported deaths from Covid-19 in the first six weeks after each country started reporting their first death from Covid-19 against the excess mortality rates from the 1918 influenza pandemic. The scatter plot is conditional on several country-level covariates, including population density, GDP per capita, percentage of population aged 70 or over, an index of individualism and Confucianism tradition, as well as the geographic regions. The conditional scatter plot suggests a positive and statistically significant correlation between the two pandemics (robust t-statistic $=3.26$, adjusted $\mathrm{R}^{2}=0.39$ )

The positive correlation reveals that some countries performing poorly in terms of mortality in the 1918 pandemic, such as Spain and Italy, also experienced fast mortality growth in the recent Covid-19 pandemic. However, the persistence between 1918 influenza and the current Covid-19 pandemic might not be a universal phenomenon for all countries. We note that some places such as Japan, Hong Kong, and Taiwan, fall below the regression line, suggesting these countries are performing much better than what their 1918 performance predicted.

Results from formal regression analysis are reported in table 2. Besides country-level mortality in the 1918 pandemic, we also include these countries' mortality rates from the SARS in 2002-03. We run cross sectional regressions of the following form 


$$
M_{i}^{\text {Covid }}=\beta_{1} \cdot M_{i}^{1918}+\beta_{2} \cdot M_{i}^{\text {SARS }}+X_{i}^{\prime} \gamma+\rho_{r}+\varepsilon_{i}
$$

where $i$ indexes countries, $M_{i}^{\text {Covid }}$ is the average daily growth rate of deaths from Covid-19 in the first six weeks since the first reported death, $M_{i}^{1918}$ is the total excess mortality rate from the 1918 influenza pandemic, $M_{i}^{S A R S}$ is the total mortality from SARS in 2002-03, $X_{i}$ includes a set of control variables, $\rho_{r}$ is a set of regional fixed effects, $r$ indexes five regions (East Asia, South Asia, Europe, the Americas, and Oceania), and $\varepsilon_{i}$ is an error term. We use heteroscedasticity robust standard errors in all specifications.

Our baseline results are reported in column (3) of Table 2. We also explore the dependent variable of the daily growth rate of confirmed cases of Covid-19 in the first six weeks after the $100^{\text {th }}$ confirmed case. These results are reported in column (4)-(6).

All these findings suggest that, even after conditioning on a set of observable characteristics, countries performing poorly in the 1918 pandemic tended to fail to control mortality growth of Covid-19 in the first month and a half of the outbreak. The point estimate of the coefficient for 1918 mortality is 0.0373 (p-value: $0.037,95 \%$ C.I.: 0.0025 to 0.0721$)^{3}$. This implies that a one standard deviation rise in 1918 mortality is associated with a 0.52 standard deviation rise in the growth rate of deaths from Covid-19.

On the other hand, there is some evidence of learning. The negative correlation between mortality from SARS and Covid-19 mortality reveals that the countries hit harder by the more recent epidemic have been more successful in slowing down the development of Covid-19 in the first several weeks and months. The point estimate of the coefficient for 2002-2003 SARS mortality is -0.13 (p-value: $0.001,95 \%$ C.I.: -0.30 to -0.06 ). This implies a one standard deviation rise in SARS mortality is associated with a fall in the growth rate of deaths from Covid-19 of 1.63 standard deviations. This is suggestive evidence that some countries strongly learned from their more recent experience.

\subsubsection{Analysis: US Cities}

Next, we examine the persistence of public health performance in a group of large U.S. cities. We compare the early trajectories of population mortality rates in the 1918 influenza and the contemporary Covid-19 pandemic. Data are for 46 cities for which high frequency data in 1918 are available.

In Figure 4, we plot the trajectory of the mortality rate (excess deaths per 100,000 population) from influenza and pneumonia and Covid-19 in the days after total deaths crossed the 0.5 per 100,000 people in those cities. ${ }^{4}$ The city-by-city comparison of historical

\footnotetext{
3 The coefficients and 95\% confidence intervals are multiplied by 1000 for better presentation.

${ }^{4}$ Excess deaths rates serve as good measurement of the severity of the 1918 pandemic across cities with potentially different seasonal influenza patterns. The threshold of $0.5 / 100,000$ is chosen to attain a comparable starting mortality rates for two epidemics across cities. Most cities in our sample reached this threshold early in both epidemics. Our results are robust to other alternative thresholds such as 1/100,000.
} 
and contemporary mortality trajectories reveals high similarity of the two epidemics in most cities.

We conduct regression analysis with daily observations for the 46 large cities. We start with regressions of the following form

$$
\ln \left(D_{c \tau}^{\text {Covid }}\right)=\pi_{1} \cdot \ln \left(D_{c \tau}^{1918}\right)+\tau+\tau^{2}+\kappa_{c}+\epsilon_{c \tau}
$$

where $c$ indexes cities, $D_{c \tau}^{\text {Covid }}$ is the number of cumulative deaths from Covid-19, $D_{c t}^{1918}$ is the number of cumulative deaths from influenza and pneumonia in 1918 in event time, and $\tau$ indexes the event time, $\kappa_{c}$ is a set of city fixed effects and $\epsilon$ is an error term. To compare the mortality from Covid-19 and 1918 influenza at a similar stage, we line up the event time for both epidemics by the number of days since the death rate reached the threshold of 0.5 per 100,000 population. We try specifications with state fixed effects to control somewhat for spatial correlation, and we also try including calendar day fixed effects instead of event time trends. As for spatial correlation, correcting the standard errors with arbitrary spatial weights makes little qualitative difference to the results. Calendar time fixed effects are highly correlated with event time which makes it hard to control for both at the same time.

Regression results are reported in Table 3 and indicate that Covid-19 deaths are positively correlated with total excess deaths in the 1918 influenza pandemic conditional on being at a similar stage in the epidemic (point estimate: 0.337, p-value: 0.000 , 95\% C.I.: 0.146-0.528). The results are robust to the alternative specifications and are not driven by the city of New York (column 4).

We also compare the growth rate of total deaths from the 1918 flu to the growth rate of deaths from Covid-19 over the first 3, 4, or 5 weeks after total mortality reached 0.5 per 100,000 population in each pandemic. In figure 5, we plot the average daily growth rate of total deaths during the two pandemics in the first 4 weeks after mortality reached 0.5 per 100,000 population. The positive correlation suggests that the cities experiencing faster mortality growth in 1918 tend to experience the same fast growth in the initial phase of Covid-19.

Regressions relating the growth rate of deaths in Covid-19 to the growth rate of deaths from the 1918 pandemic are reported in Table 4. Regressions take the form

$$
\widehat{D}_{c}^{\text {Covid }}=\theta \cdot \widehat{D}_{c}^{1918}+X_{c}^{\prime} \phi+v_{c}
$$

where $\widehat{D}_{c}^{\text {Covid }}$ denotes the average daily growth rate of deaths from Covid-19 for city $c$, $\widehat{D}_{c}^{1918}$ is the average growth rate of deaths from influenza and pneumonia, $X$ is a set of control variables, and $v$ is an error term. We condition on historical and contemporary population density and age distribution.

A positive and statistically significant correlation between the growth rates in the first 3,4 , and 5 weeks after mortality rates reached the given threshold is evident. For the first 4 
weeks, the estimated coefficient of mortality growth in the 1918 pandemic is 0.40 (p-value: $0.000,95 \%$ C.I.: 0.23 to 0.60 ). This implies a one standard deviation rise in mortality growth of the 1918 influenza is associated with a 0.43 standard deviation rise in the mortality growth from Covid-19 in the first 4 weeks.

The strong persistence of public health performance in U.S. cities could be explained by some unobservable but pre-existing or long-run persistent characteristics of the cities driving growth in both pandemics. To understand whether the identified persistence might be driven by such factors or whether historical mortality plays a more direct role in influencing health outcomes today, we employ an instrumental variable strategy.

Our excluded instrument for mortality in the 1918 flu during the early phase leverages the distance between cities and U.S. Army training camps. Historical evidence suggests that military personnel were among those who were affected early and contributed significantly to disease spread in nearby cities (Crosby, 1989; Barry, 2004; Byerly, 2010). Military camps were located across the US for training recruits for World War I in the early years of World War I. Their precise location was likely determined by strategic concerns rather than being associated drivers of public health in a pandemic. Clay et. al. (2018) use a measure of distance to military training camps as a determinant of morality from in the 1918 pandemic. Hilt and Rahn (forthcoming) use distance to military camps as an excluded instrumental variable to predict excess mortality in October 1918 while Correia, Luck, and Verner (2020) use distance weighted by the number of personnel at the bases as an excluded instrument to predict mortality from influenza in late 1918.

We construct our own index of exposure to influenza in military camps. For each city $c$, exposure is defined as $\sum_{j} \frac{\ln \left(\text { admission }_{j}\right)}{\ln \left(\text { distance }_{c j}\right)}$, where admission $_{j}$ is the number of (camp) hospital admissions due to influenza and pneumonia in military camp $j$ in the two months of August and September 1918. The variable distance ${ }_{c j}$ is the geodesic distance between city $c$ and camp $j$. For each city, we include the five closest camps in this calculation. The data on location and flu-related admissions for the major army camps come from the 1919 Annual Report of the War Department.

Figure 6 shows a simple correlation between the mortality growth of 1918 flu and the exposure to influenza in nearby military camps. The positive correlation is consistent with our hypothesis that cities more exposed to the influenza outbreaks in nearby camps had faster mortality growth in the early phase of the 1918 pandemic. This could be due to the fact that the intensity tended to be higher in the South and East where the pandemic started and where local public health systems and populations were caught off-guard. We reestimate the relationship between mortality growth of 1918 influenza and contemporary Covid-19, with two-stage least squares (2SLS).

The 2SLS estimates are reported in the Table 5. The first stage results show large Fstatistics. A weak instrumental variable is not a concern. The coefficients on mortality growth in the 1918 flu remain statistically significant and positive. These findings suggest 
that the identified positive correlation between the early performance in these two pandemics were not solely driven by potential unobservable pre-existing city characteristics. These results are some evidence that there is a plausible link between contemporary, albeit so far unidentified, drivers of modern mortality performance. We discuss some possibilities below.

\section{Discussion}

What factors inhibit prompt response and success during a pandemic? Let us assume that they include "distrust, isolationism and hubris" (Parmet and Rothstein, 2018). In our discussion it will become clear that all these factors mattered for performance in both 1918 and in 2020. These factors seem to be correlated over time across countries. It is not clear however whether these factors are recurrent features of societies which have been unfortunately timed with the outbreak of a new infectious disease like Covid-19, whether these factors indeed persist over time or whether they are exacerbated by historical experience with pandemics.

Ackerknecht (1947) suggests that public health responses in the 19th century may have reflected dominant political philosophies and even competing interest groups representing such dogmas and pardigms. "Contagionism" and "quarantinism" were often associated with a heavy handed approach to governance and seen as antithetical to commercial/economic interests. The "sanitationists" who advocated behavioral approaches and better public hygiene stemmed from a more liberal tradition. While most social distancing policies, and other NPIs, like shelter-in-place today are a far cry from the lazarettos of the past, they may in fact be the modern-day equivalents of quarantine and lockdowns. These approaches would seemingly be more appealing or viable in nations with interventionist traditions. Mainland China for instance indeed opted for intensive quarantining during Covid-19 as has been well documented. On the other hand, the so-called red states of the US, but the US more generally in a comparative context, have resisted the call to implement long duration lockdowns. The US has historically been more apprehensive of policies including lockdowns that interfere with the economy and individual liberty. In sum, long-running political cleavages may be an integral part of the explanation for societal responses to pandemics.

Mistrust may be driven by experience with historical pandemics. Modern sociopolitical pathologies may have historical roots. Aassve, Alfani and Le Moglie (2020) argue greater mortality in the 1918-20 pandemic generated lower trust in the long run. ${ }^{6}$ This may help explain some of the persistence we see in the data both across countries and within the

\footnotetext{
${ }^{5}$ Baldwin (2005) expands upon the Ackerknechtian view.

${ }^{6}$ The measure of trust is based on the General Social Survey question: "Generally speaking, would you say that most people can be trusted or that you can't be too careful in dealing with people?"
} 
US. This may also be why our instrumental variables results show that mortality in 1918 may not merely be correlated with long-run demographic or geographic features of cities.

At the country level, our regression analysis rules out individualist cultural explanations and other geographic/regional unobservable factors. The issues of distrust, hubris and isolationism return to the forefront and are evident in 1918 and now and may have even been exacerbated over the long run by earlier pandemics. This makes it less likely that simply unfortunate timing is the main explanation for the persistence of these enabling factors. On the other hand, East Asia seems to have been hit harder by the flu in 1918 and by SARS but has performed better in the early stages of Covid-19. Perhaps these nations have greater trust for other reasons that has offset some of the potential losses from past pandemics.

Whatever the case may be, history is surely not destiny nor does history repeat itself. We do not want to suggest either. The correlations we highlight in this paper emphasize that if public health objectives are to be met, societies must substitute innovative efforts to overcome adversity when other social and political forces such as "distrust, isolationism and hubris" handicap public health responses.

Still, historical experience has seemingly affected the path of mortality in the Covid19 pandemic. First, in a positive sense. Experience with SARS is likely to have promoted societal learning and reaction. Meanwhile, where the mortality of the 1918 influenza was high, mortality is likely to be high today. Why? As we discuss below, local public health "traditions" may be historically persistent, but the timing of Covid-19 and the flu of 1918 have been somewhat unfortunate as well.

\subsection{SARS and Recent History}

East Asian nations, the places most affected by SARS in 2002-03 have been more likely to act quickly to mitigate spread and to have lower mortality from Covid-19 thus far. The searing lessons of SARS, along with particular national characteristics, appear to have positively influenced pandemic preparedness. The key national characteristics for success in battling a pandemic -- trust, cooperation, and a lack of hubristic over-confidence --- are present in these nations and they have provided a favorable environment for learning from the past. Are there other explanations?

It is plausible that experience with SARS obscures national characteristics since SARS had a limited geographic reach, largely affecting selected places in East Asia. Indeed, places in East Asia like Taiwan, Singapore, Hong Kong, South Korea, Japan, and mainland China have kept reported cumulative cases and deaths from Covid-19 at low levels especially when scaled by population. The population mortality rate has averaged 0.34 per 100,000 in these six places and if we exclude Japan and China it was 0.32 . This is well below the average of 20.64 in other advanced economic nations in western Europe, the Americas and Australia as of May 21,2020 (Table 1). 
We control for regional fixed effects and some religio-philosohical and cultural traditions including "Confucianism" and collectivism. None of these eliminate the statistically significant association between past pandemics and Covid-19. Neither of these "deep" cultural factors is statistically significant. Many of these places have been at the epicenter of recent pandemics like SARS but also including MERS and the recent Covid-19 pandemic. There is strong evidence that these places saw the threat of SARS due to recent experience. Meanwhile the western nations less affected by these recent pandemics "saw the threat through the lens of influenza" according to the editor of The Lancet Richard Horton. (Ahuja, 2020).

East Asian nations appear to have used their trusted and competent technocratic civil services to learn from recent experience and to develop a high level of preparedness for a pandemic. The pandemic preparedness plans for the East Asian nations most affected by SARS often mention recent local experience with SARS. Pandemic response to Covid-19 has been swift and forceful. A host of specialized protocols have been followed including border checks of travelers for illness, international travel bans from affected regions, high rates of testing and contact tracing, social distancing, using masks and raising public awareness.

Another plausible explanation for East Asian success in the recent period may be competency and trust in the civil service. This may have allowed them to manage things better in comparative terms in this sever pandemic. China, Taiwan, Hong Kong, Japan and South Korea, the countries most affected by SARS, have an average percentage of people having "a great deal of trust" or "quite a lot of trust" in civil service of $56.68 \%$ (std. dev. $=13.96$ ) according to the 2010-2014 World Values Survey. The average of western nations available in the sample (Australia, Germany, New Zealand, Spain, Sweden and the USA) was $45.9 \%$ (std. dev. $=5.06$ ) and that for all other nations in the sample excluding these places was $42.5 \%$ (std. dev. $=19.18$ ).

The salience of events in recent living memory combined with high trust and competence in the civil service most likely helped these nations to learn from past experience. East Asian success has been built upon the realization that a new pandemic was likely given the recent experience. As one can see in Figure 1, many of these E. Asian nations are below the regression line implying better than expected performance during the early phases of Covid-19. In western nations pandemics had largely been relegated to history with influenza being the most recurrent issue. Population mortality rates from influenza have been significantly lower since 1918 and most influenza since then has had a CFR much lower than that of Covid-19.

\subsection{Influenza Mortality in 1918-20 and Covid-19 Mortality: Countries}

Today, many western nations have elected officials that have openly discussed abandoning international agreements of the post-World War 2 era. The US is not alone in this. So-called populist tendencies have emerged in many western democracies. Electoral 
success has risen, but many countries see this manifested in the strength of opposition parties like the AFD in Germany, the FN in France, and UKIP in the UK. These political movements also are amplifications of public mistrust of officials and experts. The politicization of public health responses has been highlighted (Eichengreen, 2020).

In 1918 many countries in the West were involved in all-out war. Reporting on the influenza pandemic was minimized as most historians agree. The Italian interior minister was not alone in denying the spread of the pandemic (Martini et. al, 2019). In the US, politicians downplayed the menace of the flu. Similar responses have been heard today in Italy. The mayor of Milan promoted "Milan doesn't stop" on day 6 of the Covid-19 outbreak leaving bars, restaurants, and cafes open (McCann et. al, 2020). In the United States, the president declared Covid-19 to be a "hoax" in late February 2020.

Another unfortunate similarity between today and in the past was the inadequate preparation of many health care systems for surge demand. During World War I, the US military had 300,000 physicians on duty which is over $1 / 5$ of the total number of physicians in the USA at the time. ${ }^{7}$ Other nations fighting in the war also had skewed their health infrastructure to war efforts. Today, a nearly constant discussion about equipment shortages, lack of PPE and beds in ICUs has been a common theme. Access to health care in the United States is problematic especially in places where poverty is high, inequality is high, and the social safety net is over-stretched. This characterizes the health care system in New York but in other localities in the US as well.

Finally, politics was on a knife-edge and highly polarized in many western nations in 1918. Many countries were fighting in the war, facing imminent revolutions or momentous political changes or both. Mussolini and fascists in Italy were rising to power, Spain was unstable, Russia was recovering from recent revolution. Even in the US, Woodrow Wilson's political mandate was handicapped by the narrow Republican victory in a New Mexico Senate race leading to Republican control of the Senate.

\subsection{US Cities in 1918 versus Today}

Perhaps the most striking correlation that we have uncovered is the apparent longrun correlation between mortality in 1918 and today in US cities. Again, the role of politics is manifest. Historians have found evidence that that non-pharmaceutical interventions (NPIs) mattered for peak mortality and cumulative death rates. Cities that adopted NPIs earlier and/or maintained them longer had some success in keeping these variables lower, especially peak mortality. Cities like Philadelphia which delayed and allowed a "Liberty Bond" rally to go ahead have been compared unfavorably to St. Louis which limited public gatherings and sustained school closures. St. Paul has been compared to Minneapolis and

\footnotetext{
${ }^{7}$ Number of medical personnel in the military as of November 1918 300,000 (Statistical Abstract of the United States of America, 1919, p. 728). Number of physicians in the United states in 19201.542 million according to Carter et. al. (2006).
} 
San Francisco has been compared to New York. In the former pair St. Paul delayed longer in implementing NPIs than Minneapolis suffering the consequences. San Francisco implemented a mask ordinance in mid-October 1918 while New York implemented light touch social distancing. At the time there was much debate about how far to go with these measures and about their effectiveness. For instance, the Anti-Mask League of San Francisco was a political force in late 1918. Opponents of William Hassler, the city Public Health Officer who promoted mask-wearing, also attempted to murder him such was their mis-trust and dislike of his public health policies. Dr. Anthony Fauci, director of the National Institute of Allergy and Infectious Disease, and a key proponent of social distancing, was given a security detail in late March against "un-specified threats" (Diamond, 2020).

Across US cities there has been political debate on the effectiveness of social distancing and NPIs. It is interesting that the mayors of San Francisco and New York had opposing viewpoints in March on how to handle Covid-19. While mayor London Breed of San Francisco emphasized pandemic preparedness for a major disruption on 2 March, Mayor Bill de Blasio of New York was "encouraging New Yorkers to go on with your lives" on twitter even making a recommendation for watching a movie in a cinema. Historian John M. Barry has emphasized that Tammany (a corrupted political machine) was in control of New York in 1918 and had appointed Royal Copeland, a homeopath, as president of the New York City Board of Health. Copeland downplayed the epidemic at first and failed to close schools. Copeland went on to become a US Senator. Hassler would eventually become the president of the American Public Health Association. Perhaps the trust in local government that was lost in 1918 never returned.

None of this is to ascribe the correlations we have found to extreme persistence in public health capabilities and the politics of public. However, the coincidence of divergent opinions and political and social malaise in the West is notable. It is impossible to blame the disease itself on these issues. It may however be possible to credit slow response times and delayed action to these matters. In other words, while history has not repeated itself, certain outcomes are remarkably similar. 


\section{References}

Aassve, A., Alfani, G., Gandolfi, F. and Le Moglie, M. 2020. "Epidemics and Trust: The Case of the Spanish Flu". IGIfaER working paper no. 661.

Ackerknecht, E.H. 1974 Anticontagionism between 1821 and 1867. Bulletin of the History of Medicine 1948; 22, pp. 562-593.

Ahuja, Anjana. 2020. "Richard Horton: 'It's the biggest science policy failure in a generation'”. Financial Times, 25 April, 2020.

Baldwin, P. 2005 Contagion and the State in Europe, 1830-1930. Cambridge: Cambridge University Press.

Barro, R. J., Ursùa, J. F., and Weng, J. 2020. The Coronavirus and the Great Influenza Pandemic: Lessons From the "Spanish Flu" For The Coronavirus's Potential Effects On Mortality And Economic Activity. NBER WP 26866.

Barry, J M. The Great Influenza: The Epic Story of the Deadliest Plague in History. New York: Viking Press Books, 2004.

Bootsma, M.C. and Ferguson, N.M., 2007. The effect of public health measures on the 1918 influenza pandemic in US cities. Proceedings of the National Academy of Sciences, 104(18), pp.7588-7593.

Carter ,Susan B. et. al. (eds.) Historical statistics of the United States (Online) (Millennial edition). New York: Cambridge University Press.

Centers for Disease Control and Prevention 2007. "Interim Pre-Pandemic Planning Guidance: Community Strategy for Pandemic Influenza Mitigation in the United StatesEarly, Targeted, Layered Use of Nonpharmaceutical Interventions. Department of Health and Human Services. US Government.

Center for Systems Science and Engineering (CSSE) at Johns Hopkins University, Covid-19 Dashboard.

Clay, K., Lewis, J. and Severnini, E. 2018. Pollution, Infectious Disease, and Mortality: Evidence from the 1918 Spanish Influenza Pandemic. The Journal of Economic History, vol 78 (4), pp. 1179-1209.

Collins, S.D., Frost, W.H., Gover, M. and Sydenstricker, E., 1930. Mortality from influenza and pneumonia in 50 large cities of the United States, 1910-1929. Ann Arbor, Michigan: Michigan Publishing, University Library, University of Michigan. 
Crosby, A.D. America's Forgotten Pandemic: The Influenza of 1918. New York: Cambridge Univ. Press, 1989.

Eichengreen, Barry 2020. “Coronanomics 101" Project Syndicate 10 March 2020.

Diamond, D. 2020. "Fauci gets security detail after receiving threats" Politico 1 April, 2020. Downloaded on 28 April, 2020 from https://www.politico.com/news/2020/04/01/faucicoronavirus-security-160901

Hatchett, R.J., Mecher, C.E. and Lipsitch, M., 2007. "Public health interventions and epidemic intensity during the 1918 influenza pandemic." Proceedings of the National Academy of Sciences, 104(18), pp.7582-7587.

Hilt, E. and Rahn. W.M. Forthcoming. "Financial Asset Ownership and Political Partnership: Liberty Bonds and Republican Electoral Success in the 1920s," Journal of Economic History.

Johnson, N.P. and Mueller, J., 2002. "Updating the accounts: global mortality of the 19181920 `Spanish' influenza pandemic”. Bulletin of the History of Medicine, pp.105-115.

Markel, H., Lipman, H.B., Navarro, J.A., Sloan, A., Michalsen, J.R., Stern, A.M. and Cetron, M.S., 2007. "Nonpharmaceutical interventions implemented by US cities during the 1918-1919 influenza pandemic". JAMA, 298(6), pp.644-654.

Martini, M., Gazzaniga, V., Bragazzi, N.L. and Barberis, I., 2019. "The Spanish Influenza Pandemic: a lesson from history 100 years after 1918". Journal of Preventive Medicine and Hygiene, 60(1), p.E64.

McCann, A., Popovich, N. and Wu, J. 2020 “Italy's Virus Shutdown Came Too Late. What Happens Now?" New York Times 5 April, 2020. Downloaded on 28 April, 2020. https://www.nytimes.com/interactive/2020/04/05/world/europe/italy-coronaviruslockdown-reopen.html

Morens, D.M. and Fauci, A.S., 2007. "The 1918 influenza pandemic: insights for the 21st century." The Journal of infectious diseases, 195(7), pp.1018-1028. 
Parmet, W.E. and Rothstein, M.A., 2018. "The 1918 Influenza Pandemic: Lessons Learned and Not-Introduction to the Special Section." American Journal of Public Health 108 (11) pp. 1435-1436.

Short, K.R., Kedzierska, K. and van de Sandt, C.E., 2018. "Back to the future: lessons learned from the 1918 influenza pandemic". Frontiers in cellular and infection microbiology, 8, p.343.

Statistical Abstract of the United States of America. 1919. Bureau of the Census. Washington: Government Printing Office.

Verity et. al. 2020. "Estimates of the severity of COVID-19 disease". Medrxiv posted March 13, 2020. Downloaded 4/25/2020.

https://www.medrxiv.org/content/10.1101/2020.03.09.20033357v1

War Department (US). Annual Report, 1919. Volume 1 Report of the Surgeon General, Washington: Government Printing Office. 


\section{Figure 1 Mortality Rate per 100,000 Covid-19 and 1918-20 Influenza Pandemics: Cross-Country Evidence}

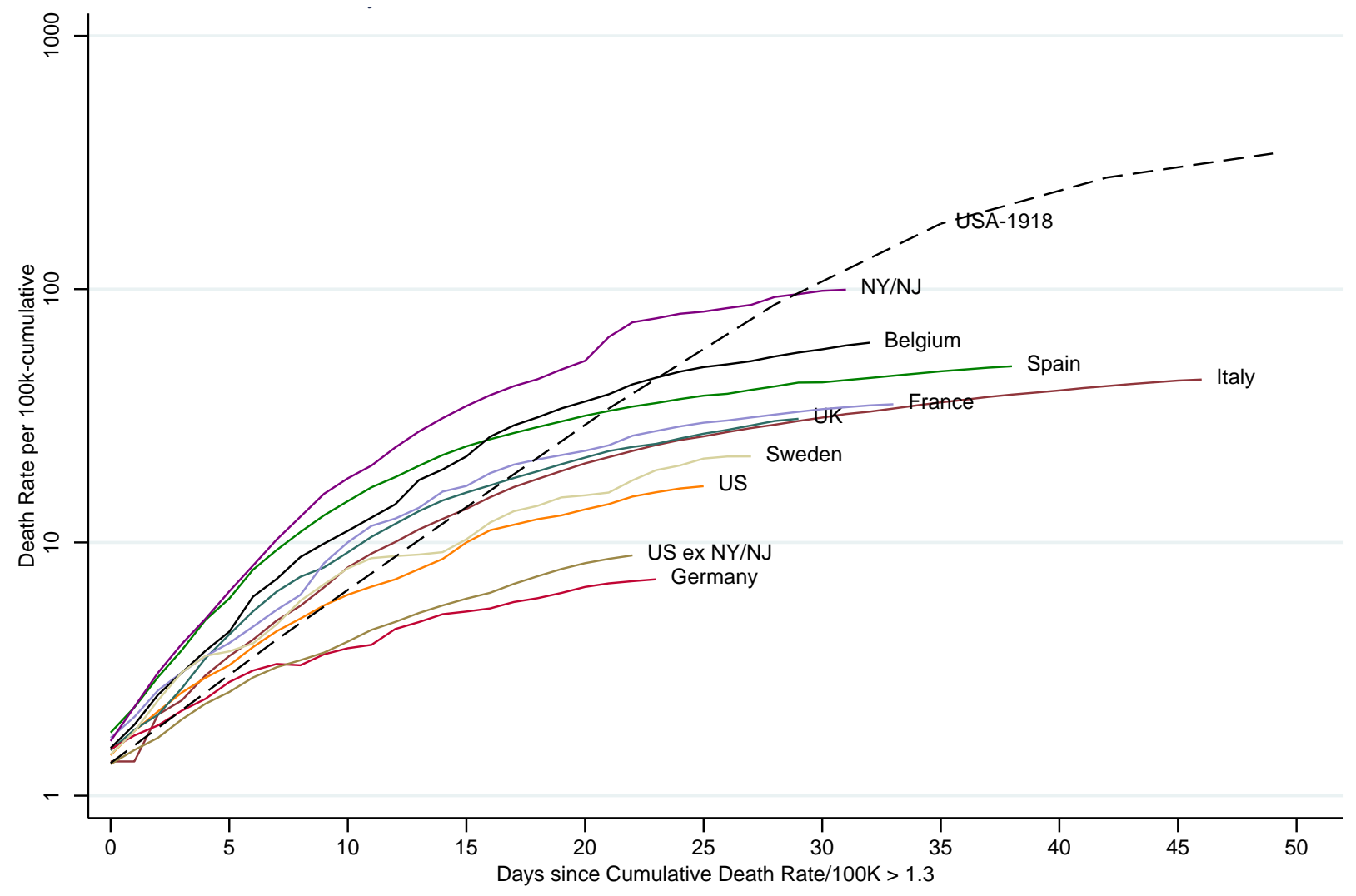

Notes: Figure shows the population mortality rates of Covid-19 based on data from CSSE Johns Hopkins. We break the data for the US into three parts: mortality for the entire US, mortality rates for the states of New York and New Jersey, the hardest hit states and for the US excluding these two states. Data for the Influenza pandemic of 1918 are for total weekly deaths per 100k from influenza and pneumonia for data from 46 cities in the USA (Collins et. al. 1930). Data are plotted for countries in 2020 that had reached a threshold of 1.34 deaths per 100,000. This is the first available level of the mortality rate in the 1918 for the national level data for the USA. Data from 2020 are as of 27 April 2020. 
Figure 2 Mortality Rate per 100,000 Covid-19 and 1918-20 Influenza Pandemics: US States

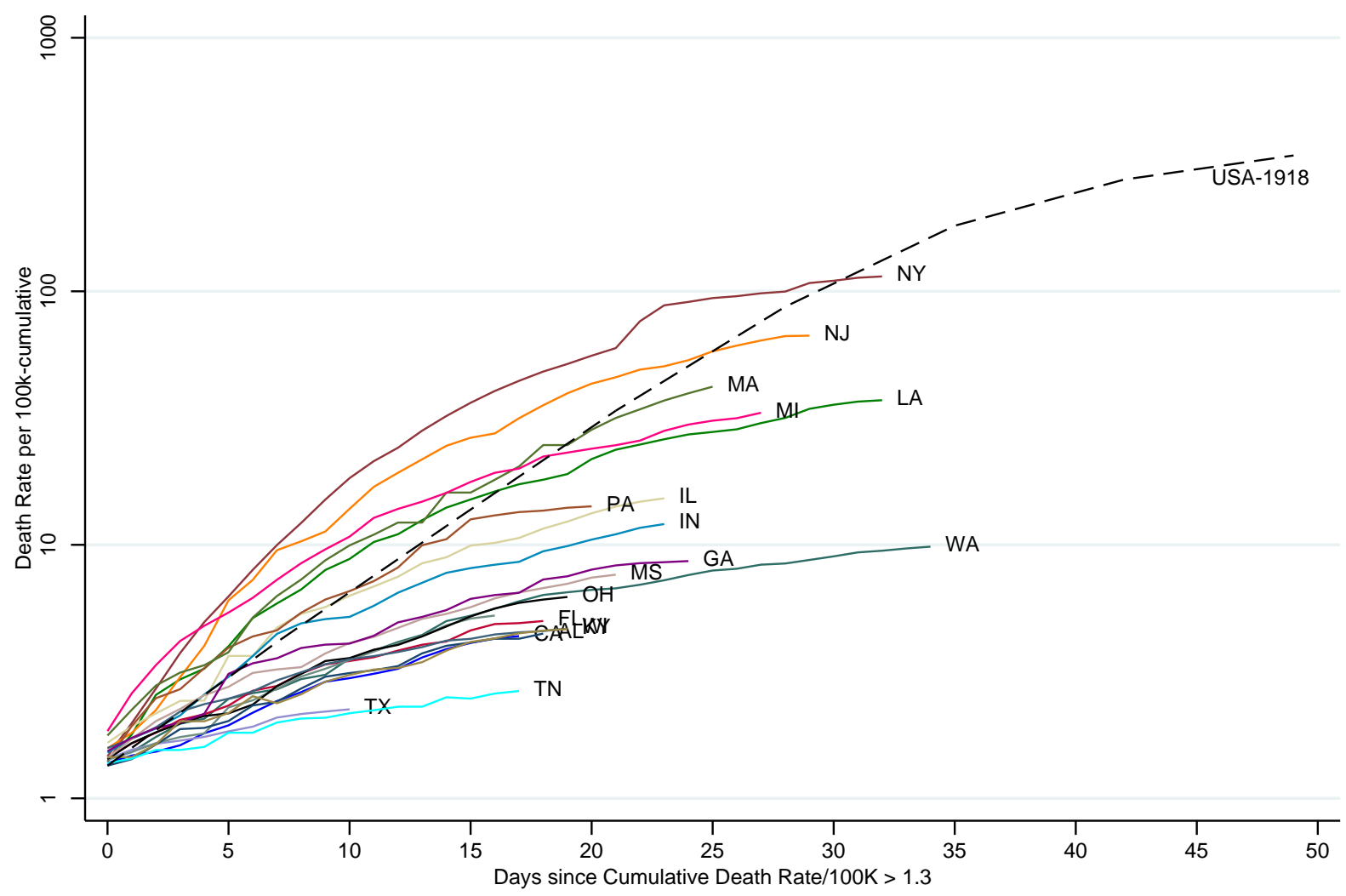

Notes: Figure shows the population mortality rates of Covid-19 based on data from CSSE Johns Hopkins. Data for the Influenza pandemic of 1918 are as described in the notes to Figure 1. Data for Covid-19 are as of 27 April 2020. 
Figure 3 Mortality of 1918-20 Influenza and Covid-19 Pandemics, 32 Countries

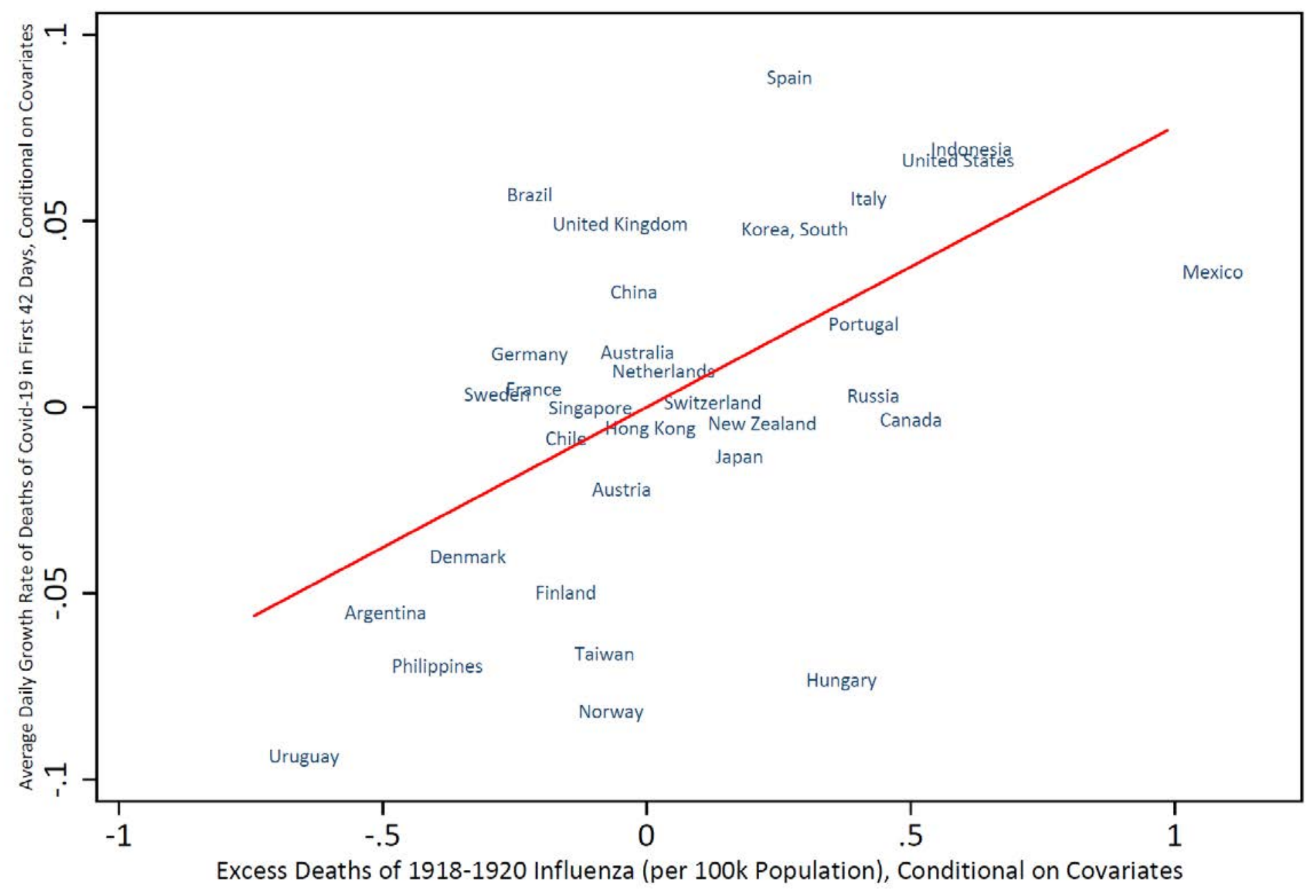

Notes: This graph plots the average daily growth rate of total deaths from Covid-19 in the first 6 weeks since the first death in each country against the estimated excess mortality rate from the 1918 Influenza pandemic, both conditional on a set of country-level covariates. Data are described in the data

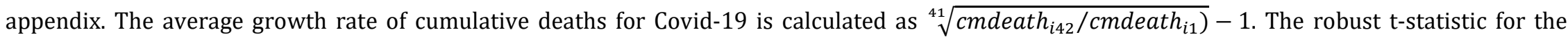
coefficient on deaths from influenza in 1918 is $=3.26$, and the regression has an adjusted $\mathrm{R}^{2}=0.69$. 
Figure 4 Mortality Curves for Covid-19 and Influenza and Pneumonia in 1918 in Selected U.S. Cities
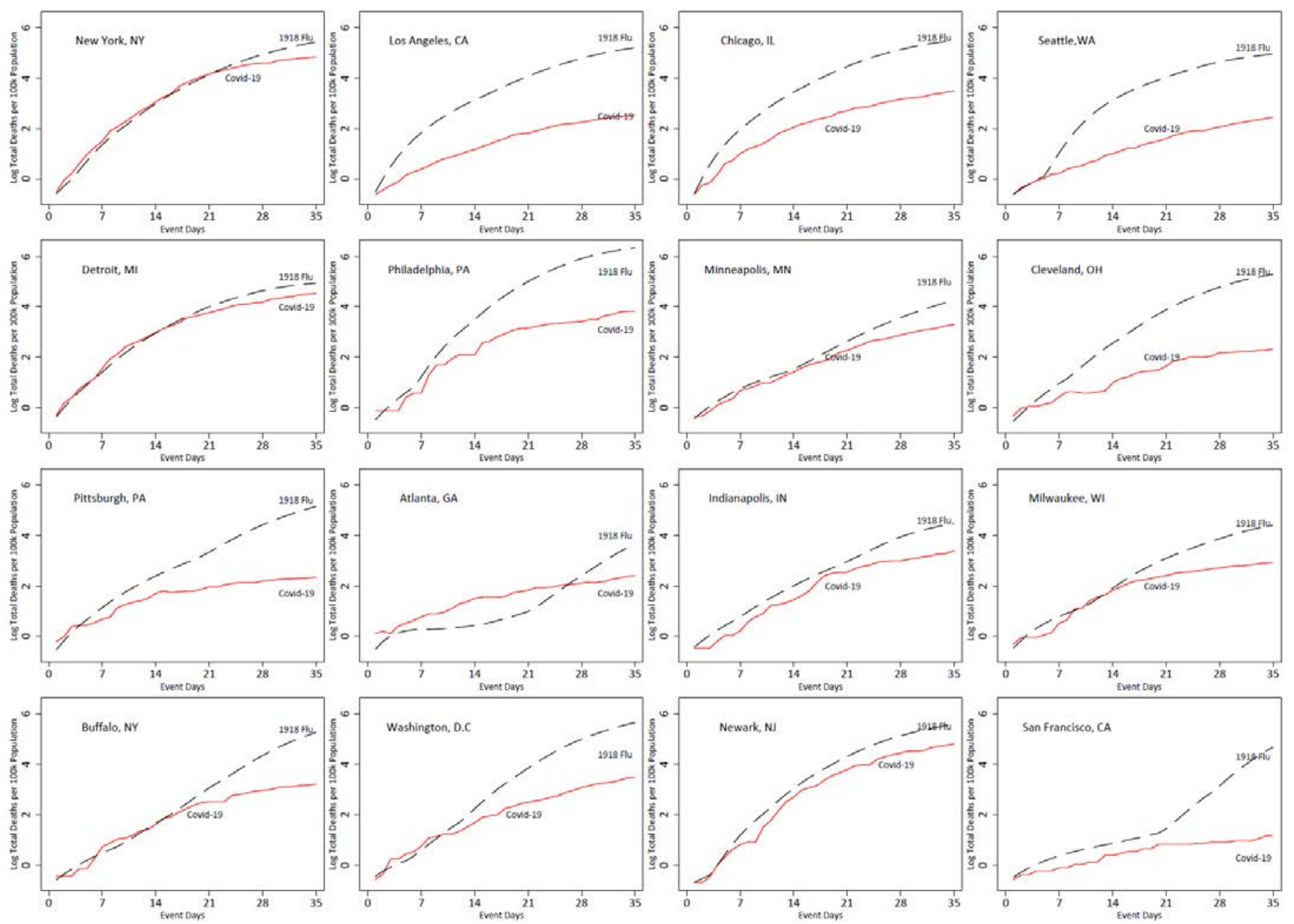

Notes: These charts provide city-by-city comparisons between the trajectories of population mortality rate from influenza and pneumonia in 1918 and Covid-19 in 2020. We plot the logarithm of total deaths per 100,000 (for Covid-19) or total excess deaths per 100,000 (for 1918 influenza and pneumonia) on the $y$-axis versus the number of days since mortality rates reached $0.5 / 100,000$ population. The 16 cities present here are those with largest population in 2019. Trajectories for other cities are available upon request from authors. 
Figure 5 Average Daily Growth of Total Deaths from Covid-19 and Influenza and Pneumonia in U.S. Cities: First 28 Days

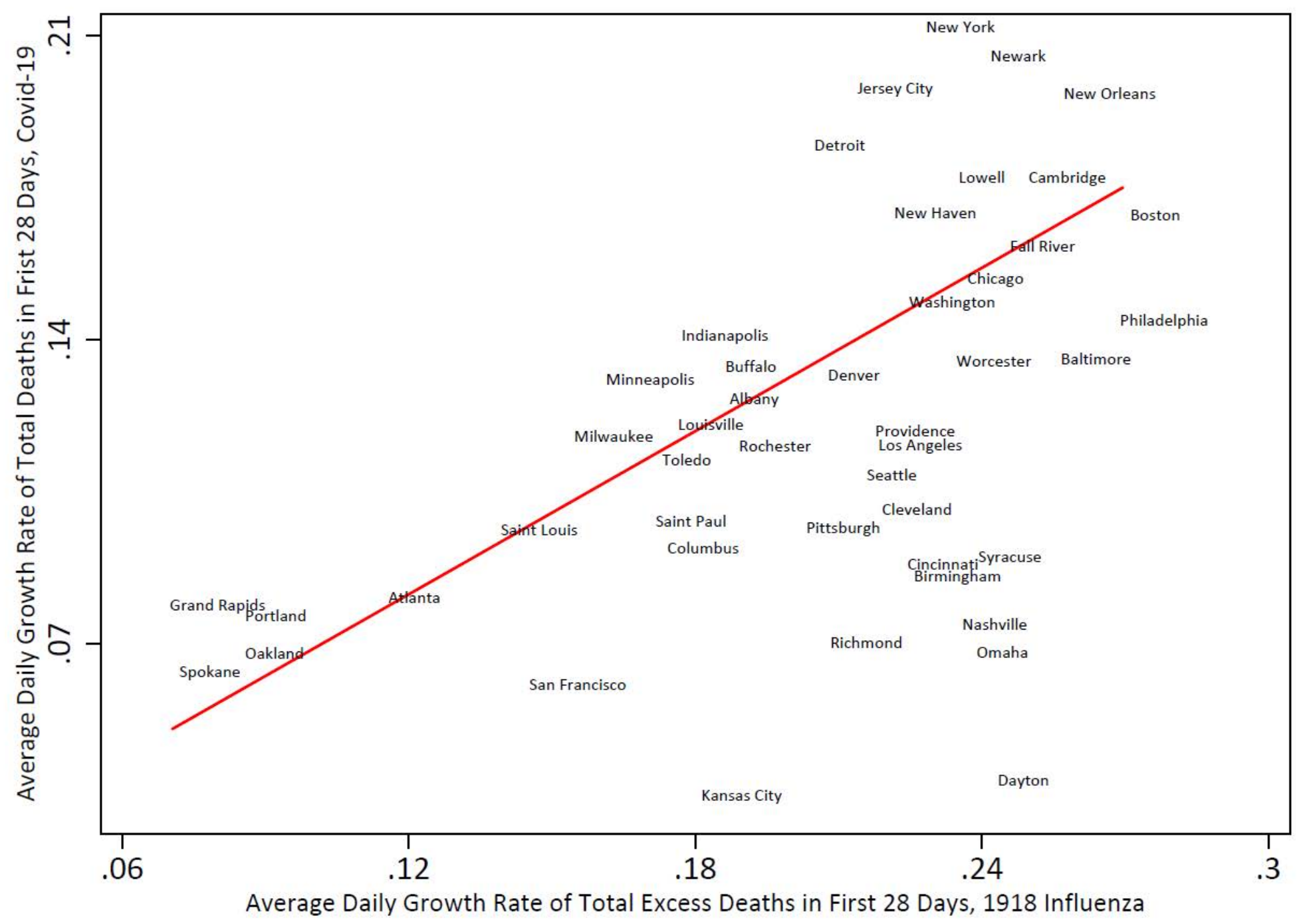

Notes: Chart shows the unconditional relationship between the average daily growth rate of total deaths during Covid-19 in the first 21 days compared to the average growth rate of excess deaths in the first 21 days of the 1918-20 pandemic. The coefficient of the regression (which includes a constant) is 0.355 with a robust $t$-statistic of 4.09 and a $95 \%$ C.I. of 0.179 to 0.531 . The average daily growth rates of total deaths (or total excess deaths for 1918 influenza) in the first 21 days are calculated by $\sqrt[20]{\left.\text { cmdeath }_{i t} / \text { cmdeath }_{i t-20}\right)}-1$. The first 21 days refer to the 21 days since the total deaths (for Covid-19) or total excess deaths (for 1918 Influenza) reached 0.5 for every 100,000 population. 
Figure 6 Mortality Growth of 1918 Influenza and Exposure to U.S. Army Camps

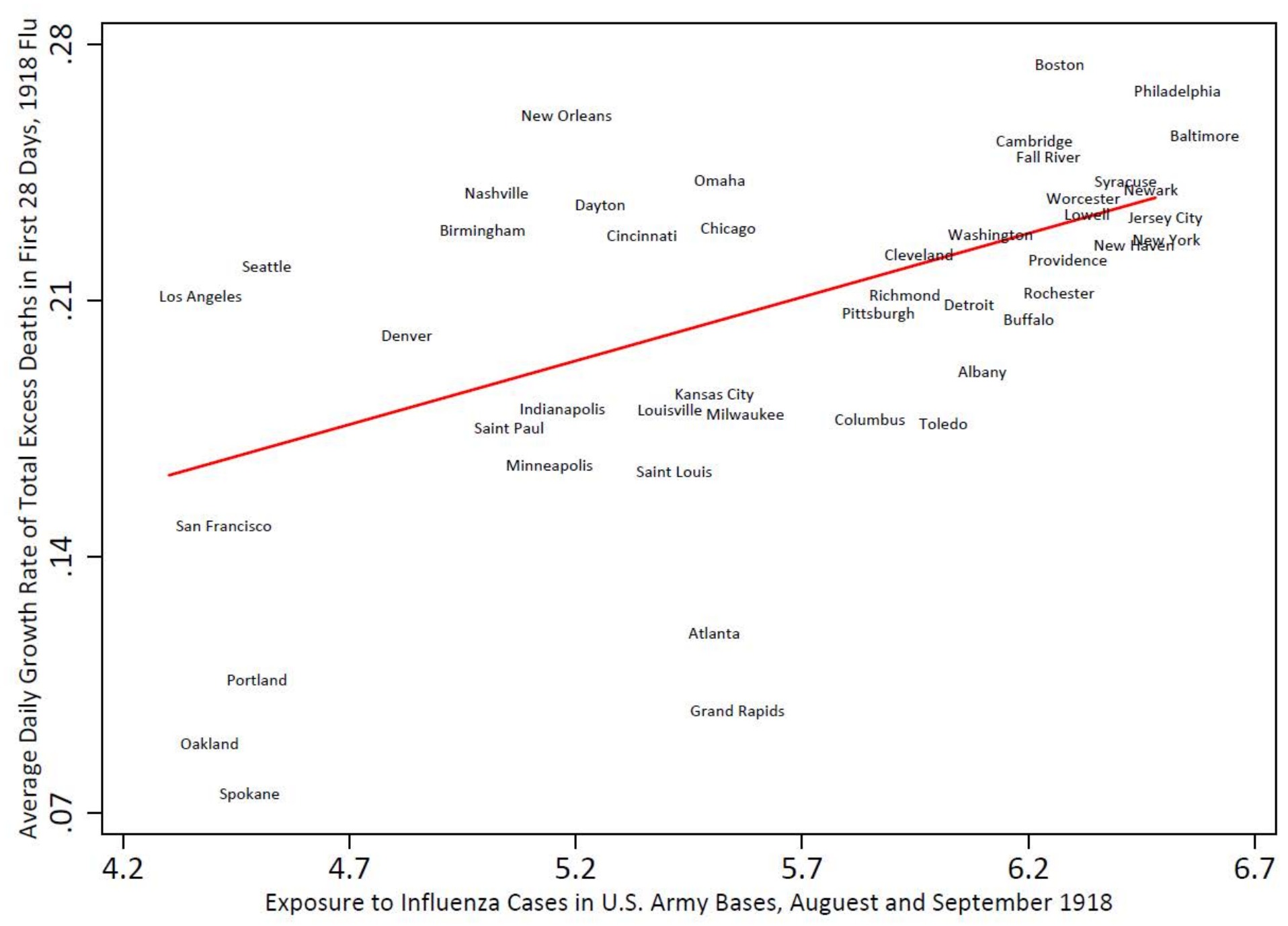

Note: The data of influenza and pneumonia admissions by major military camps are from the Report of the Surgeon General, which is Volume 1 of the War Department Annual Report of 1919. We have 39 major army camps and the distance between cities and camps are determined by the distance between cities and the counties these camps located in. The exposure to Influenza cases in camps is defined as $\sum_{j} \frac{\ln \left(\text { admission }_{j}\right)}{\ln \left(\text { distance }_{c j}\right)}$, where admission ${ }_{j}$ is the number of hospital admissions due to influenza and pneumonia in the military camp $j$, in the two months of August and September, 1918. 
Table 1 Mortality Rates of for Three Pandemics: 1918-20 Influenza, 2002-03 SARS, and Covid-19

\begin{tabular}{|c|c|c|c|}
\hline Country & $\begin{array}{l}\text { Mortality Rates of } \\
\text { 1918-20 Influenza } \\
\text { (per 100,000) }\end{array}$ & $\begin{array}{c}\text { Mortality Rates of } \\
2002-2003 \text { SARS } \\
\text { (per } 100,000)\end{array}$ & $\begin{array}{c}\text { Mortality Rates of } \\
\text { Covid-19 by May } \\
21,2020 \\
\text { (per } 100,000 \text { ) }\end{array}$ \\
\hline Argentina & 330 & 0 & 0.93 \\
\hline Australia & 280 & 0 & 0.4 \\
\hline Austria & 970 & 0 & 7.07 \\
\hline Brazil & 690 & 0 & 9.50 \\
\hline Canada & 620 & 0.131 & 3.62 \\
\hline Chile & 860 & 0 & 3.11 \\
\hline Denmark & 780 & 0 & 9.72 \\
\hline Finland & 710 & 0 & 5.53 \\
\hline France & 740 & 0.002 & 43.25 \\
\hline Germany & 780 & 0 & 9.82 \\
\hline Hungary & 1270 & 0 & 4.88 \\
\hline Italy & 1230 & 0 & 53.65 \\
\hline Mexico & 2060 & 0 & 5.10 \\
\hline Netherlands & 710 & 0 & 33.78 \\
\hline New Zealand & 690 & 0 & 0.43 \\
\hline Norway & 570 & 0 & 4.37 \\
\hline Portugal & 1810 & 0 & 12.49 \\
\hline Russia & 1870 & 0 & 2.12 \\
\hline Spain & 1360 & 0 & 59.78 \\
\hline Sweden & 630 & 0 & 38.57 \\
\hline Switzerland & 760 & 0 & 22.09 \\
\hline United Kingdom & 460 & 0 & 53.44 \\
\hline United States & 650 & 0 & 28.61 \\
\hline Uruguay & 220 & 0 & 0.58 \\
\hline \multirow[t]{2}{*}{ Average } & 1128 & 0.0035 & 20.64 \\
\hline & \multicolumn{3}{|c|}{ Asian Countries } \\
\hline China & 1430 & 0.027 & 0.32 \\
\hline India & 5220 & 0 & 0.26 \\
\hline Indonesia & 3040 & 0 & 0.47 \\
\hline Japan & 960 & 0 & 0.61 \\
\hline South Korea & 1380 & 0 & 0.52 \\
\hline Philippines & 1880 & 0.002 & 0.78 \\
\hline
\end{tabular}




\begin{tabular}{cccc}
\hline \hline Singapore & 1290 & 0.79 & 0.40 \\
Taiwan & 1070 & 0.799 & 0.03 \\
Hong Kong & 238 & 4.448 & 0.05 \\
\hline Average & 2759 & 0.03 & 0.34 \\
Average & 4637 & 0.04 & 0.32 \\
(ex. China and Japan) & & & \\
\hline \hline
\end{tabular}

Notes: Estimates of mortality rates of 1918 Influenza come from the recalculation and compilation by Johnson and Mueller (2002) except for Hong Kong, South Korea, and Singapore. For the latter three see the data appendix for sources. Mortality rates for 2002-2003 SARS come from WHO and include the deaths from cases from November 1, 2002 to July 31, 2003. Mortality rates for Covid-19 come from the CSSE of Johns Hopkins University. Population-weighted averages are presented for each region. 
Table 2 Covid-19 Pandemics and Mortality from 1918 Influenza and SARS, Country-Level Evidence

\begin{tabular}{|c|c|c|c|c|c|c|}
\hline & $\begin{array}{l}\quad(1) \\
\text { Average Daily } \\
\text { Growth Rate of } \\
\text { Total Deaths of } \\
\text { Covid-19 }\end{array}$ & $\begin{array}{c}\text { (2) } \\
\text { Average Daily } \\
\text { Growth Rate of } \\
\text { Total Deaths of } \\
\text { Covid-19 }\end{array}$ & $\begin{array}{c}\text { (3) } \\
\text { Average Daily } \\
\text { Growth Rate of } \\
\text { Total Deaths of } \\
\text { Covid-19 }\end{array}$ & $\begin{array}{l}\text { (4) } \\
\text { Average Daily } \\
\text { Growth Rate of } \\
\text { Total Cases of } \\
\text { Covid-19 }\end{array}$ & $\begin{array}{c}\text { (5) } \\
\text { Average Daily } \\
\text { Growth Rate of } \\
\text { Total Cases of } \\
\text { Covid-19 }\end{array}$ & $\begin{array}{c}\text { (6) } \\
\text { Average Daily } \\
\text { Growth Rate of } \\
\text { Total Cases of } \\
\text { Covid-19 }\end{array}$ \\
\hline & $\begin{array}{l}42 \text { Days since } \\
\text { First Death }\end{array}$ & $\begin{array}{l}42 \text { Days since } \\
\text { First Death }\end{array}$ & $\begin{array}{l}42 \text { Days since } \\
\text { First Death }\end{array}$ & $\begin{array}{l}42 \text { Days since } \\
100^{\text {th }} \text { Case }\end{array}$ & $\begin{array}{l}42 \text { Days since } \\
100^{\text {th }} \text { Case }\end{array}$ & $\begin{array}{l}42 \text { Days since } \\
100^{\text {th }} \text { Case }\end{array}$ \\
\hline $\begin{array}{l}\text { Total Mortality Rate of } \\
\text { 1918-20 Influenza }\end{array}$ & $\begin{array}{c}0.0275^{* * *} \\
(0.00882)\end{array}$ & $\begin{array}{l}0.0369^{* *} \\
(0.0165)\end{array}$ & $\begin{array}{l}0.0373^{* *} \\
(0.0167)\end{array}$ & $\begin{array}{c}0.0163^{* *} \\
(0.00686)\end{array}$ & $\begin{array}{c}0.0230^{*} \\
(0.0132)\end{array}$ & $\begin{array}{c}0.0235^{*} \\
(0.0135)\end{array}$ \\
\hline $\begin{array}{l}\text { Total Mortality Rate of } \\
\text { SARS }\end{array}$ & $\begin{array}{l}-0.0120^{* *} \\
(0.00555)\end{array}$ & $\begin{array}{l}-0.127^{* * *} \\
(0.0366)\end{array}$ & $\begin{array}{l}-0.132^{* * *} \\
(0.0337)\end{array}$ & $\begin{array}{l}-0.00659 \\
(0.00438)\end{array}$ & $\begin{array}{l}-0.0765^{*} \\
(0.0375)\end{array}$ & $\begin{array}{l}-0.0823^{* *} \\
(0.0370)\end{array}$ \\
\hline $\begin{array}{l}\text { Population Density in } \\
2019 \text { (10k per Square } \\
\text { Miles) }\end{array}$ & & $\begin{array}{c}0.311^{* * *} \\
(0.0953)\end{array}$ & $\begin{array}{c}0.323^{* * *} \\
(0.0893)\end{array}$ & & $\begin{array}{c}0.189^{*} \\
(0.0936)\end{array}$ & $\begin{array}{c}0.203^{* *} \\
(0.0948)\end{array}$ \\
\hline $\begin{array}{l}\text { Log (GDP per capita in } \\
2018 \text { ) }\end{array}$ & & $\begin{array}{l}0.00923 \\
(0.0252)\end{array}$ & $\begin{array}{c}0.0127 \\
(0.0293)\end{array}$ & & $\begin{array}{l}0.00534 \\
(0.0219)\end{array}$ & $\begin{array}{l}0.00911 \\
(0.0236)\end{array}$ \\
\hline $\begin{array}{l}\text { Confucianism Tradition } \\
(0 / 1)\end{array}$ & & $\begin{array}{l}-0.541^{* * *} \\
(0.163)\end{array}$ & $\begin{array}{l}-0.564^{* * *} \\
(0.155)\end{array}$ & & $\begin{array}{c}-0.322 \\
(0.191)\end{array}$ & $\begin{array}{l}-0.348^{*} \\
(0.191)\end{array}$ \\
\hline $\begin{array}{l}\text { Individualism Index } \\
(0 / 100)\end{array}$ & & $\begin{array}{c}0.000951 \\
(0.000759)\end{array}$ & $\begin{array}{c}0.000975 \\
(0.000773)\end{array}$ & & $\begin{array}{c}0.000680 \\
(0.000636)\end{array}$ & $\begin{array}{c}0.000706 \\
(0.000652)\end{array}$ \\
\hline $\begin{array}{l}\text { Percentage of } \\
\text { Population, Age }>=70\end{array}$ & & & $\begin{array}{l}-0.00171 \\
(0.00465)\end{array}$ & & & $\begin{array}{l}-0.00185 \\
(0.00358)\end{array}$ \\
\hline Observations & 33 & 33 & 33 & 33 & 33 & 33 \\
\hline$R^{2}$ & 0.549 & 0.670 & 0.672 & 0.331 & 0.453 & 0.459 \\
\hline
\end{tabular}

Notes: Dependent variables in columns (1)-(3) is the average daily growth rate of total deaths of Covid-19 in the first 42 days since first death case. Dependent variable in columns (4)-(6) is the average daily growth rate of total confirmed cases of Covid-19 in the first 42 days since the $100^{\text {th }}$ confirmed cases. Estimation is by OLS. The estimated coefficients and standard errors on the total mortality rate of 1918-20 influenza were multiplied by 1000 for presentational purposes. All regressions control for region fixed effects (the sample covers 5 regions: East Asia, South Asia, Europe, Americas, and Oceania). Robust standard errors are reported in parentheses. ${ }^{*} \mathrm{p}<0.1,{ }^{* *} \mathrm{p}<0.05,{ }^{* * *} \mathrm{p}<0.01$. 
Table 3 Mortality of Covid-19 and 1918 Influenza in 46 U.S. Cities, Daily Data

\begin{tabular}{|c|c|c|c|c|c|}
\hline & $\begin{array}{c}(1) \\
\ln \text { (Total Deaths } \\
\text { per 100,000, } \\
\text { Covid-19 } \\
\text { All Cities) }\end{array}$ & $\begin{array}{c}(2) \\
\text { ln (Total Deaths } \\
\text { per 100,000, } \\
\text { Covid-19 } \\
\text { All Cities) }\end{array}$ & $\begin{array}{c}(3) \\
\ln (\text { Total Deaths } \\
\text { per 100,000, } \\
\text { Covid-19 } \\
\text { All Cities } \\
\text { Unweighted) }\end{array}$ & $\begin{array}{c}(4) \\
\text { In (Total Deaths } \\
\text { per 100,000, } \\
\text { Covid-19 } \\
\text { Exc. NYC) }\end{array}$ & $\begin{array}{c}(5) \\
\ln \text { (Total Deaths } \\
\text { per 100,000, } \\
\text { Covid-19 } \\
\text { All Cities) }\end{array}$ \\
\hline $\begin{array}{l}\text { In (Total Excess Deaths } \\
\text { per } 100,000,1918 \mathrm{Flu})\end{array}$ & $\begin{array}{c}0.342^{* * *} \\
(0.0838)\end{array}$ & $\begin{array}{c}0.337^{* * *} \\
(0.0927)\end{array}$ & $\begin{array}{c}0.217^{* * *} \\
(0.0751)\end{array}$ & $\begin{array}{c}0.222^{* * *} \\
(0.0602)\end{array}$ & $\begin{array}{c}0.240^{* * *} \\
(0.0703)\end{array}$ \\
\hline Event Days & $\begin{array}{c}0.122^{* * *} \\
(0.0124)\end{array}$ & $\begin{array}{c}0.123^{* * *} \\
(0.0129)\end{array}$ & $\begin{array}{c}0.130^{* * *} \\
(0.0140)\end{array}$ & $\begin{array}{c}0.127^{* * *} \\
(0.0123)\end{array}$ & \\
\hline (Event Days) $^{2}$ & $\begin{array}{l}-0.00196^{* * *} \\
(0.000270)\end{array}$ & $\begin{array}{l}-0.00198^{* * *} \\
(0.000260)\end{array}$ & $\begin{array}{l}-0.00200^{* * *} \\
(0.000216)\end{array}$ & $\begin{array}{l}-0.00184^{* * *} \\
(0.000188)\end{array}$ & \\
\hline Observations & 1610 & 1610 & 1610 & 1575 & 1598 \\
\hline$R^{2}$ & 0.888 & 0.939 & 0.908 & 0.935 & 0.973 \\
\hline Calendar Date F.E. & No & No & No & No & Yes \\
\hline State F.E. & Yes & No & No & No & No \\
\hline City F.E. & No & Yes & Yes & Yes & Yes \\
\hline
\end{tabular}

Notes: Dependent variables are the logarithm of total deaths of Covid-19 per 100,000 population. These and total excess death rates from the 1918-20 influenza are at the daily level. All specifications control for state or city fixed effects. Event days are defined as the days since total deaths (for Covid-19) or total excess deaths (for 1918 Influenza) reached 0.5/100,000 population. The data on Covid-19 were last updated on 21May, 2020. The full list of cities can be found in data appendix and are the same as those from Collins et. al (1930). All regressions are weighted by population in 2019, except for the column (3). Standard errors are clustered at the state level and reported in the parentheses. ${ }^{*} p<0.1,{ }^{* *} p<0.05,{ }^{* * *} p<0.01$. 
Table 4 Growth of Total Deaths of Covid-19 and 1918 Influenza in U.S. Cities: OLS Estimates

\begin{tabular}{|c|c|c|c|c|c|}
\hline & (1) & (2) & (3) & (4) & (5) \\
\hline & $\begin{array}{l}\text { Average Daily } \\
\text { Growth Rate of } \\
\text { Total Deaths, } \\
\text { Covid-19 } \\
\text { First } 28 \text { Days }\end{array}$ & $\begin{array}{l}\text { Average Daily } \\
\text { Growth Rate of } \\
\text { Total Deaths, } \\
\text { Covid-19 } \\
\text { First } 28 \text { Days }\end{array}$ & $\begin{array}{l}\text { Average Daily } \\
\text { Growth Rate of } \\
\text { Total Deaths, } \\
\text { Covid-19 } \\
\text { First } 28 \text { Days }\end{array}$ & $\begin{array}{l}\text { Average Daily } \\
\text { Growth Rate of } \\
\text { Total Deaths, } \\
\text { Covid-19 } \\
\text { First } 21 \text { Days }\end{array}$ & $\begin{array}{c}\text { Average Daily } \\
\text { Growth Rate o } \\
\text { Total Deaths, } \\
\text { Covid-19 } \\
\text { First } 35 \text { Days }\end{array}$ \\
\hline $\begin{array}{l}\text { Average Daily Growth Rate of } \\
\text { Total Excess Deaths, } 1918 \text { Flu, } \\
\text { First } N \text { Days }\end{array}$ & $\begin{array}{l}0.626^{* * *} \\
(0.132)\end{array}$ & $\begin{array}{c}0.390^{* * *} \\
(0.0790)\end{array}$ & $\begin{array}{c}0.398^{* * *} \\
(0.0835)\end{array}$ & $\begin{array}{c}0.282^{* * *} \\
(0.0481)\end{array}$ & $\begin{array}{l}0.521^{* * *} \\
(0.137)\end{array}$ \\
\hline Population Density, 2019 & & $\begin{array}{c}0.142^{* *} \\
(0.0625)\end{array}$ & $\begin{array}{c}0.139^{* *} \\
(0.0606)\end{array}$ & $\begin{array}{c}0.216^{* *} \\
(0.0866)\end{array}$ & $\begin{array}{c}0.0919^{*} \\
(0.0478)\end{array}$ \\
\hline Population Density, 1920 & & $\begin{array}{c}0.247^{* * *} \\
(0.0850)\end{array}$ & $\begin{array}{c}0.214^{* *} \\
(0.0999)\end{array}$ & $\begin{array}{c}0.239 \\
(0.144)\end{array}$ & $\begin{array}{c}0.187^{* *} \\
(0.0801)\end{array}$ \\
\hline $\begin{array}{l}\text { Percentage of Population Age } \\
65 \text { and Over, } 2019\end{array}$ & & & $\begin{array}{l}-0.00126 \\
(0.00289)\end{array}$ & $\begin{array}{l}-0.000271 \\
(0.00376)\end{array}$ & $\begin{array}{l}-0.00208 \\
(0.00242)\end{array}$ \\
\hline $\begin{array}{l}\text { Percentage of Population Age } \\
65 \text { and Over, } 1920\end{array}$ & & & $\begin{array}{l}-0.00164 \\
(0.00251)\end{array}$ & $\begin{array}{l}-0.00281 \\
(0.00347)\end{array}$ & $\begin{array}{l}-0.00129 \\
(0.00221)\end{array}$ \\
\hline \# Cities & 46 & 46 & 46 & 46 & 46 \\
\hline $\mathrm{R}^{2}$ & 0.278 & 0.681 & 0.685 & 0.704 & 0.639 \\
\hline
\end{tabular}

Notes: The average daily growth rates of total deaths for first $n$ days are calculated by $\sqrt[n-1]{\left.c m d e a t h_{i t} / c m d e a t h_{i n-1}\right)}-1$. The first $n$ days refers to the days since total deaths (for Covid-19) and total excess deaths (for 1918 Influenza) reached 0.5 for every 100,000 people. All regressions are weighted by population in 2019. Standard errors are clustered at the state level and reported in the parentheses. ${ }^{*} p<0.1,{ }^{* *} p<0.05,{ }^{* * *} p<0.01$. 
Table 5 Growth of Total Deaths of Covid-19 and 1918 Influenza in U.S. Cities: 2SLS Estimates

\begin{tabular}{|c|c|c|c|c|c|}
\hline & (1) & $(2)$ & (3) & $(4)$ & (5) \\
\hline & $\begin{array}{l}\text { Average Daily } \\
\text { Growth Rate of } \\
\text { Total Deaths, } \\
\text { Covid-19 } \\
\text { First } 28 \text { Days }\end{array}$ & $\begin{array}{l}\text { Average Daily } \\
\text { Growth Rate of } \\
\text { Total Deaths, } \\
\text { Covid-19 } \\
\text { First } 28 \text { Days }\end{array}$ & $\begin{array}{l}\text { Average Daily } \\
\text { Growth Rate of } \\
\text { Total Deaths, } \\
\text { Covid-19 } \\
\text { First 28 Days }\end{array}$ & $\begin{array}{l}\text { Average Daily } \\
\text { Growth Rate of } \\
\text { Total Deaths, } \\
\text { Covid-19 } \\
\text { First } 21 \text { Days } \\
\end{array}$ & $\begin{array}{c}\text { Average Daily } \\
\text { Growth Rate of } \\
\text { Total Deaths, } \\
\text { Covid-19 } \\
\text { First } 35 \text { Days } \\
\end{array}$ \\
\hline $\begin{array}{l}\text { Average Daily Growth Rate of } \\
\text { Total Excess Deaths, } 1918 \text { Flu, } \\
\text { First } N \text { Days }\end{array}$ & $\begin{array}{l}1.392^{* * *} \\
(0.520)\end{array}$ & $\begin{array}{l}0.645^{* *} \\
(0.257)\end{array}$ & $\begin{array}{l}0.598^{* * *} \\
(0.215)\end{array}$ & $\begin{array}{l}0.449^{* * *} \\
(0.146)\end{array}$ & $\begin{array}{l}0.866^{* *} \\
(0.345)\end{array}$ \\
\hline Population Density, 2019 & & $\begin{array}{c}0.153^{* *} \\
(0.0666)\end{array}$ & $\begin{array}{c}0.148^{* *} \\
(0.0623)\end{array}$ & $\begin{array}{c}0.226^{* * *} \\
(0.0874)\end{array}$ & $\begin{array}{c}0.0945^{*} \\
(0.0509)\end{array}$ \\
\hline Population Density, 1920 & & $\begin{array}{c}0.179 \\
(0.121)\end{array}$ & $\begin{array}{l}0.0694 \\
(0.136)\end{array}$ & $\begin{array}{l}0.0663 \\
(0.181)\end{array}$ & $\begin{array}{l}0.0527 \\
(0.122)\end{array}$ \\
\hline $\begin{array}{l}\text { Percentage of Population Age } \\
65 \text { and Over, } 2019\end{array}$ & & & $\begin{array}{l}-0.00277 \\
(0.00317)\end{array}$ & $\begin{array}{l}-0.00198 \\
(0.00470)\end{array}$ & $\begin{array}{l}-0.00381 \\
(0.00249)\end{array}$ \\
\hline $\begin{array}{l}\text { Percentage of Population Age } \\
65 \text { and Over, } 1920\end{array}$ & & & $\begin{array}{l}-0.00730^{* *} \\
(0.00339)\end{array}$ & $\begin{array}{l}-0.00914^{* *} \\
(0.00453)\end{array}$ & $\begin{array}{l}-0.00657^{* *} \\
(0.00304)\end{array}$ \\
\hline$K$-P F-Statistics for IV & 21.97 & 13.19 & 13.86 & 10.82 & 11.15 \\
\hline \# Cities & 46 & 46 & 46 & 46 & 46 \\
\hline $\mathrm{R}^{2}$ & -0.104 & 0.592 & 0.643 & 0.669 & 0.568 \\
\hline
\end{tabular}

Notes: The instrumental variable for the average daily growth rates of 1918 influenza is the exposure to flu-related admissions in military camps in August and September in 1918. The average daily growth rates of total deaths for first $n$ days are calculated by $\sqrt[n-1]{\left.c m d e a t h_{i t} / c m d e a t h_{i n-1}\right)}-1$. The first $n$ days refers to the days since total deaths (for Covid-19) and total excess deaths (for 1918 Influenza) reached 0.5 for every 100,000 people. All regressions are also weighted by population in 1920 . Standard errors are clustered at state level and reported in the parentheses. ${ }^{*} p<0.1,{ }^{* *} p<0.05$, ${ }^{* * *} p<0.01$. 


\section{Data Appendix}

\section{Cross-Country Data, 1918}

Mortality rates: Johnson and Mueller (2002). Data for UK are for England, Wales and Scotland. Data for Ireland are for Eire; Singapore deaths from Lee et. al. (2007); Korea from Hong et. al (2017); Hong Kong data from Cheng and Leung (2007). Hong Kong population in 1919 calculated from Swee-Hock and Wing King (1975); Singapore, population Dodge (1980)

Excess mortality: Murray, Lopez, Chin, Feehan, Hill (2006)

Population density, GDP per capita: Data underlying Clemens and Williamson (2004). All data for 1919.

Population (000s) and GDP per capita (1990 real US Dollars) from Maddison; when unavailable Clemens and Williamson (2004). Data are interpolated where necessary.

Land area from google searches when unavailable in Clemens and Williamson (2004). Land area in square miles.

\section{Covid-19 Data, 2020}

Data for cases and deaths by country for Covid-19 from European Centre for Disease Prevention and Control https://data.europa.eu/euodp/en/data/dataset/covid-19-coronavirus-data/resource/55e8f966-d5c8438e-85bc-c7a5a26f4863 downloaded on April 27, 2020.

\section{Regional Fixed Effects}

The 33 countries in our cross-country sample are categorized in 5 major regions:

East Asia: Mainland China, Hong Kong, Taiwan, Japan, and South Korea.

South Asia: India, Indonesia, Philippines, and Singapore.

Europe: Austria, Denmark, Finland, France, Germany, Hungary, Italy, Netherlands, Norway, Portugal, Russia, Spain, Sweden, Switzerland, and United Kingdom.

The Americas: Argentina, Brazil, Canada, Chile, Mexico, United States, and Uruguay.

Oceania: Australia and New Zealand.

\section{Density, GDP per capita, and other Control Variables}

The population density and age distribution of sample countries come from the World Population Prospects 2019, by the United Nations. Details can be found:

https://population.un.org/wpp/Download/Standard/CSV/ 
GDP per capita in 2018 comes from the World Bank and is in constant 2010 U.S. dollars. Details can be found: https://data.worldbank.org/indicator/NY.GDP.PCAP.KD

Countries coded to have a Confucianist tradition include Mainland China, Hong Kong, Taiwan, Japan, South Korea, and Singapore.

The measurement of individualism index comes from the 6-dimensional model of national culture by Geert Hofstede. The index is based on the Values Survey in 2013 (Geert Hofstede and Michael Minkov, 2013).

Details of the 6-dimensional model can be found

https://geerthofstede.com/culture-geert-hofstede-gert-jan-hofstede/6d-model-of-national-culture/

\section{Cities in the US Sample:}

The 46 cities in our analysis include: Albany (NY), Atlanta (GA), Baltimore (MD), Birmingham (AL), Boston (MA), Buffalo (NY), Cambridge (MA), Chicago (IL), Cincinnati (OH), Cleveland (OH), Columbus (OH), Dayton $(\mathrm{OH})$, Denver (CO), Detroit (MI), Fall River (MA), Grand Rapids (MI), Indianapolis (IN), Jersey City (NJ), Kansas City (MO), Los Angeles (CA), Louisville (KY), Lowell (MA), Milwaukee (WI), Minneapolis (MN), Nashville (TN), New Haven (CT), New Orleans (LA), New York City (NY), Newark (NJ), Oakland (CA), Omaha (NE), Philadelphia (PA), Pittsburgh (PA), Portland (OR), Providence (RI), Richmond (VA), Rochester (NY), Saint Louis (MO), Saint Paul (MN), San Francisco (CA), Seattle (WA), Spokane (WA), Syracuse (NY), Toledo (OH), Washington D.C., Worcester (MA).

\section{8-1919 Influenza Pandemic in U.S. Cities}

The mortality data in 46 major U.S. cities come from the public health reports (Collins, 1930). ${ }^{8}$ We interpolate the weekly excess deaths to daily basis by linear interpolation. Then, we calculate the cumulative excess deaths from the week of September 14,1918, when continuous weekly deaths became available in Collins (1930). For cities with negative excess deaths in the mid-September, we start counting total deaths when excess deaths became continuously positive.

8 The original reports by Collins (1930) includes 47 cities. We exclude the city of Memphis from our analysis as its weekly mortality data are not available until the week of October 12, 1918. 
References for data appendix

Cheng, K.F. and Leung, P.C., 2007. What happened in China during the 1918 influenza pandemic? International Journal of Infectious Diseases, 11(4), pp.360-364.

Clemens, M.A. and Williamson, J.G., 2004. Wealth bias in the first global capital market boom, 1870-1913. The Economic Journal, 114(495), pp.304-337.

Dodge, Nicholas N. "Population Estimates for the Malay Peninsula in the Nineteenth Century, with Special Reference to the East Coast States." Population Studies 34, no. 3 (1980): 437-75. Accessed April 4, 2020. doi: $10.2307 / 2174803$.

Hong, S.C. and Yun, Y., 2017. Fetal exposure to the 1918 influenza pandemic in colonial Korea and human capital development. Seoul Journal of Economics, 30(4).

Johnson, N.P. and Mueller, J., 2002. Updating the accounts: global mortality of the 1918-1920" Spanish" influenza pandemic. Bulletin of the History of Medicine, pp.105-115.

Lee, V.J., Chen, M.I., Chan, S.P., Wong, C.S., Cutter, J., Goh, K.T. and Tambyah, P.A., 2007. Influenza pandemics in Singapore, a tropical, globally connected city. Emerging infectious diseases, 13(7), p.1052.

Murray, C.J., Lopez, A.D., Chin, B., Feehan, D. and Hill, K.H., 2006. Estimation of potential global pandemic influenza mortality on the basis of vital registry data from the 1918-20 pandemic: a quantitative analysis. The Lancet, 368(9554), pp.2211-2218.

Swee-Hock, Saw, and Chiu Wing Kin. "Population Growth and Redistribution in Hong Kong, 1841-1975." Southeast Asian Journal of Social Science 4, no. 1 (1975): 123-31. 
